\title{
Treatment of venous ulcer in the elderly: implications for nursing
}

\begin{abstract}
Introduction: It is biologically noteworthy that aging is marked by progressive changes in cells, tissues and organs that impact the functional capacity of the elderly and provide a more susceptible condition in relation to chronic diseases. These factors contribute to the increased risk of loss of skin integrity and, consequently, the appearance of ulcers.

Goal: To characterize the content available in the scientific literature about the therapeutic methods of topical use for the treatment of venous ulcer in the elderly. Method: This is an integrative review of literature, a method whose purpose is to group and synthesize research results on a theme. A survey of 67 articles was carried out, which after passing the exclusion criteria, there were 5 articles for analysis.
\end{abstract}

Results: The selected publications were arranged in two thematic categories: Treatment of Venous Ulcer in the Elderly Person and Nursing Performance in the Treatment of Venous Ulcer in the Elderly.

Conclusion: The analysis of these studies evidences the importance of the nurse as an active and indispensable member throughout the process of treatment of venous ulcer in the elderly person. Emphasized that the systematization of nursing care is determinant for a good recovery of these clients.

Keywords: varicose ulcer, venous insufficiency, venous thrombosis, elderly, nursing
Volume 3 Issue 4 - 2018

\author{
Maurício Caxias de Souza,' Helaine dos \\ Santos Araújo, ${ }^{2}$ Thays Társsila Soares Martins \\ da Silva, ${ }^{2}$ Severina Ferreira Santos de Farias, ${ }^{2}$ \\ Danilo Rocha Lins ${ }^{3}$ \\ 'Research Professor, State University of Milagro, Brazil \\ ${ }^{2}$ Department of Nurse, Brazil \\ ${ }^{3}$ Doctor, Federal University of Rondônia, Brazil
}

Correspondence: Maurício Caxias de Souza, Research Professor, State University of Milagro, Brazil,Tel

+5583988926868, Email mauriciocaxias_@hotmail.com

Received: June 27, 2018 | Published: July 12, 2018

\section{Introduction}

There are estimates that in the coming decades there will be a growth of 841 million for two billion people over 60 in the world by the year 2050 and close to three billion by $2100 .{ }^{1}$ No Brasil, a população com essa faixa etária passou de 14,9 milhões (7,4\% do total) em 2013, e passará para 58,4 milhões (26,7\% do total) em 2060 segundo dados do Instituto Brasileiro de Geografia e Estatística (IBGE). ${ }^{2}$

As far as the biological perspective is concerned, aging is marked by progressive changes in cells, tissues and organs that have an impact on the functional capacity of the elderly and provide a more susceptible condition in relation to chronic diseases. These factors contribute to the increased risk of loss of skin integrity and, consequently, the appearance of venous ulcers. ${ }^{3}$ Venous ulcers are currently considered a public health problem. They contribute to the increase in the number of early retirements, causing loss of active labor force. ${ }^{4}$ In addition, elderly discomfort, withdrawal from social interaction, and possible impairments of the functional capacity of the subject. ${ }^{5}$

The aging process alone can compromise the individual's quality of life and may be even more compromising when the elderly person has a venous lesion. The long period of living with a wound causes difficulties to be faced by its sufferers, and such changes involve the various aspects of the life of that individual. ${ }^{6}$ Nursing plays an important role during the intervention process to improve the quality of life of this elderly person. Its implications during the recovery/ stabilization process are of fundamental importance in the life of this subject as a biopsychosocial being. ${ }^{\text {? }}$

The presence of ulcers can cause a number of implications in the biopsychosocial aspects of elderly life, directly interfering with their quality of life pattern. According to the World Health Organization, quality of life is an individual perception of the individual's position in life in the context of their culture and value system in which they are inserted and in relation to their goals, expectations, standards and concerns. ${ }^{8}$ Thus, we can consider that the nurse's role in the attention to the elderly patient submitted to venous ulcer treatment is still little distinguished among health professionals. It is important to show the nursing care to this patient, since these are specific care. However, this study is justified by the need for studies that characterize the content available in the scientific literature about the therapeutic methods of topical use for the treatment of venous ulcer in the elderly and its implications for nursing. Soon, the following questions emerged: What is the scientific knowledge available in the literature about topical therapeutic methods for the treatment of venous ulcer in the elderly and its implications for nursing? Given the above, considering the importance of the topic in evidence, the objective of this research was: to characterize the studies published in online journals about the treatment of venous ulcer in the elderly and its implications for nursing, published between 2008 and 2018, in the Virtual Health Library (VHL).

\section{Method}

The present study was an integrative literature review. This method has the purpose of grouping and synthesising research results on a given topic, in an organized way so that it contributes to a deepening of the knowledge about the question addressed. ${ }^{9}$ This method has been used in the production of articles, dissertations and theses in the health area in recent decades.

An integrative review of the literature on the scientific production based on the treatment of venous ulcer in the elderly was carried out and the implications for nursing, in the national and international context, in the health area. This method allows "[...] the search, critical evaluation and synthesis of available evidence of the subject under investigation". ${ }^{9}$ The use of this method allows as a result the current 
situation of knowledge about the topic addressed, the implementation of interventions in health care and the identification of gaps that need further study in the subject. For the elaboration of this study, the six stages of the integrative review were used, as cited by Mendes, Silveira and Galvão (2008) in order to organize the collected information:

1st stage: elaboration of the guiding question. Its definition is the most important phase because it determines the identification of what should be approached to contemplate the proposed theme.

2nd stage: search or sampling in the literature. The search was carried out in a wide and diversified way in the reliable databases, taking into account that the determination of inclusion and exclusion criteria for material selection should be carried out in accordance with the guiding question.

Step 3: Data collection. At this stage we defined what would be extracted from the selected studies through the use of a previously elaborated instrument, with the purpose of organizing the key information in a concise way to construct the study.

Step 4: Critical analysis of included studies. At this stage, data analysis was performed in detail to ensure the validity of the review. Always taking the guiding question into account as a basis for.

Step 5: discussion of results. In this phase the results obtained in the research were discussed and a critical analysis was carried out on what was evidenced.

Step 6: presentation of the integrative review. This is the phase where the study was properly drafted.

Containing enough information for the reader to make an analysis of the study carried out. To guide this integrative review, the following question was elaborated: what scientific knowledge is available in the literature on the therapeutic methods of topical use for the treatment of venous ulcer in the elderly and its implications for nursing? The articles were selected from the Virtual Health Library (VHL) database: LILACS (Latin American and Caribbean Literature in Health Sciences), BDENF - Nursing (Nursing Database) and MEDLINE (Medical Literature Analysis and Retrieval System Online). The descriptors used were: varicose ulcer; venous insufficiency; venous thrombosis; elderly; nursing, through the Boolean operators "AND" and "THE", in order to facilitate the searches of the indexed materials in the databases.

The research universe consisted of online articles in the field of health related to the treatment of venous ulcer in the elderly and its implications for nursing through access to the VHL database. The sample was determined considering the following inclusion criteria: they are available in the selected databases, contemplate the proposed theme, are available in full text, are publications of the type article, from 2008 to 2018. The exclusion criteria were: dissertations and theses, are in Spanish, as well as complete texts unavailable and do not contemplate the proposed theme.

The data collection was performed by means of an instrument (form) and occurred between May 2018. The information contained in said instrument aimed at the characterization and contributions of selected publications in order to meet the proposed research objectives. These are: article identification, professional training of authors, database, year and origin of the publication, focus given to the theme and contribution of the study. A total of 67 articles were found, of which 40 did not respond to the guiding question, 22 were repeated in the databases searched, which resulted in the selection of 05 articles to compose the sample of this integrative review.

Information extracted from the studies was collected in an instrument that gathered and summarized the key information, which had to cover the title of the article, year of publication, authors, periodical, modality, origin, methodology, database, objective and contribution of the study (Appendix A). The data of the studies included in the research were categorized, analyzed and discussed, establishing relationships with the theoretical basis in focus.

\begin{tabular}{|c|c|}
\hline & Article title \\
\hline & Year \\
\hline & Autors \\
\hline & Newspaper \\
\hline & Modality \\
\hline & Source \\
\hline & Method \\
\hline & Data base \\
\hline & Goal \\
\hline & Contribution of the Study \\
\hline
\end{tabular}

\section{Results and discussion}

\section{Characterization of the studies}

Of the 05 articles selected and included in the present study and according to the appropriate inclusion criteria, 03 studies, resulting in $80 \%$, are found in the database of the BDENF, while 01 study, resulting in $10 \%$, are found in the LILACS database, and 01 study, resulting in $10 \%$, is in the MEDLINE database, resulting finally in $100 \%$ of the sample. Below we have Table 1 that shows the characteristics of the articles used in the sample.

Table I Characteristics of studies included in the integrative review sample

\begin{tabular}{|c|c|c|c|c|}
\hline Year & Title & Authors & Method & Data base \\
\hline 2012 & $\begin{array}{l}\text { The individual with leg ulcer and structured nursing care intervention: a } \\
\text { systematic literature review }\end{array}$ & $\begin{array}{l}\text { Fonseca } \mathrm{C} \text { et } \\
\text { al. }^{\prime \prime}\end{array}$ & Systematic review & BDENF \\
\hline 2013 & Expert system to support the decision in topical therapy for venous ulcers & $\begin{array}{l}\text { Sellmer D et } \\
\text { al. }^{10}\end{array}$ & $\begin{array}{l}\text { Development } \\
\text { Research }\end{array}$ & BDENF \\
\hline 2014 & $\begin{array}{l}\text { Limits and possibilities experienced by nurses in the treatment of women } \\
\text { with chronic venous ulcers }\end{array}$ & Silva $\mathrm{MH}$ et al. ${ }^{15}$ & $\begin{array}{l}\text { Phenomenological } \\
\text { study }\end{array}$ & BDENF \\
\hline 2015 & Influence of venous ulcer in patients' quality of life: an integrative review & $\begin{array}{l}\text { Santos LSF et } \\
\text { al. }^{12}\end{array}$ & Integrative Review & LILACS \\
\hline 2018 & Factors associated with quality of life of people with chronic complex wounds & $\begin{array}{l}\text { Almeida WA } \\
\text { et al. }{ }^{13}\end{array}$ & $\begin{array}{l}\text { Cross-sectional } \\
\text { study }\end{array}$ & MEDLINE \\
\hline
\end{tabular}


Article 1 aimed to identify the nursing interventions to the person with leg ulcer of venous, arterial or mixed origin. Exploratory study, systematic approach. The results showed that a person-centered intervention increased the health outcomes, ranging from direct care to the wound depending on the etiology. As interventions associated with leg ulcer healing of any etiology, the following stand out: nursing/client therapeutic relationship, individualization of care and pain monitoring. It was concluded that the foundation of nursing care for clients with leg ulcers regardless of etiology, is based on the establishment of a therapeutic relationship that allows the collection of detailed information about the client and the surrounding nucleus, the problems that he perceives as his the level of affection of their daily living activities.

The design of the study in study 02 aimed to present a specialist system to support the decision process of nurses in the topical therapy of venous ulcers. The data found in the study showed the need for a good planning of the nursing care systematization to carry out this task. The study suggests that the system may assist in decision making on topical venous ulcers, however, assessment of the ulcer should be performed correctly in order for the system to provide appropriate suggestions, allowing better organization and planning of the care.

The objective of study 03 was to understand the experiences and expectations of nurses in the treatment of women with chronic venous ulcer in Primary Health Care. This research is based on the social phenomenology of Alfred Schütz, with testimonials obtained in January 2012 through semi-structured interview with seven nurses. Based on research, it was concluded that the treatment of chronic venous ulcer constitutes a challenge that requires collective investment, involving women, professionals, managers and health institutions.

Article 4 aimed to identify in the literature the influence of venous ulcer on patients' quality of life. Among the results obtained by the study, the most prevalent factors were the factors that influence the quality of life of a person with venous ulcer, and which cause low quality of life were: pain, limitation/restrictions in activities of daily living and quality of treatment/assistance provided. It is believed in this study that it is possible to improve the quality of life of these patients by the assistance, use of treatments proven effective as the use of compressive therapy and investing in new research that allow greater knowledge about the difficulties faced by patients.

Article 05 analyzed the quality of life of people with complex chronic wounds. Data were collected through a questionnaire containing the WHOQOL-Bref instrument of the World Health Organization and questions on sociodemographic and clinical variables. For statistical analysis, the following methods were used: Linear Correlation of Pearson; Analysis of Variance and Tukey with reliability of $95 \%$ and $p$ $<0.05$. It was concluded that the clinical characteristics and quality of life can be better understood and improved care planning contributing to the improvement of quality of life.

\section{Thematic categories}

In this section of the study will be analyzed and discussed the scientific productions on the Treatment of Venous Ulcer in the Elderly: implications for nursing. To organize the development of the presentation, the studies were divided into two thematic categories: (01) Treatment of Venous Ulcer in the Elderly; (02) Nursing Practice in the Treatment of Venous Ulcer in Elderly Person.

\section{Treatment of venous ulcer in the elderly}

According to statistical research, venous ulcers, or leg ulcers, affect $1 \%$ to $2 \%$ of the world population, with more incidents in people over 65 years of age, directly interfering with their quality of life, since are considered chronic conditions. They arise as a consequence of chronic venous hypertension, due to chronic venous insufficiency, caused by difficulty in venous return in cases of deep venous thrombosis and venous blood reflux, constituting chronic wounds affecting the lower limbs. ${ }^{10}$

The elderly affected by venous ulcers can have their quality of life impaired by several factors, among them the bad smell; abundant exudation; the pain; reduced mobility; decreased sleep; social isolation; the long time for ulcer healing; and frequent dressing changes that lead to dependence on specialized care and the need for many visits to health facilities. ${ }^{11}$

The venous ulcer is very complex and the many possibilities of treatment require of the nurse a joint structure of knowledge suitable for its correct management. The care of people with acute and chronic wounds, among them leg ulcers, is one of the focuses of attention of the nursing specialty in estomaterapia, being the nurse estomaterapeuta the professional with knowledge, training and ability to care with any type of wound acute or chronic, and this should guarantee and improve the level of individual and collective health of this clientele, based on specialized work. ${ }^{12}$

Decision support to nurses stems from the knowledge base integrated into the system, which will indicate the best topical management for venous ulcers, as well as the respective products associated with that topical management. For a better exploration and analysis, it was observed in the studies that after the patient's registry, with details of the appearance of venous ulcers, such as odor, tissue type and exudate, the system analyzes the assigned values and suggests some procedures. When accepting a treatment suggestion, the products linked to that treatment are presented, being possible to launch the quantity of products used, thus maintaining an updated cost control. This control may be a resource for the administrative process that involves the care of these ulcers, as well as its use to analyze the cost and benefit with respect to the use of conduits. ${ }^{13,11}$

For example, for situations in which the professional is unaware of the procedure or products that were suggested by the system studied in the verified sample, an online glossary with explanations was created. The user can select the product or treatment to obtain its description. ${ }^{10}$

A few experiments were performed and two cases were selected for demonstration. The first case refers to MJS, 67 years old, female, with venous insufficiency diagnosed 12 years ago in the MIE, physical examination showed edema, ITB $=0.8$, ulcer in a malleolar region measuring $7.8 \mathrm{~cm}$ in length by $5.2 \mathrm{~cm}$ wide, with granulation tissue at the edges and smears at the center of the ulcer, with exudate in moderate quantity, with no odor. When recording the characteristics of the ulcer in the system, the knowledge base is consulted, searching for rules that may help in indicating the most appropriate conduct. In this context the following rules have been executed ${ }^{10}$ IF ITB $>0.8$ and ulcer with moderate exudation and no infection. THEN Raise MMII for half an hour and use calcium alginate OR hydrofibra and unna boot OR Raise MMI for half an hour and use calcium alginate or hydrofibra and graduated elastic compression bandage. END IF; IF ulcer with shreds. THEN Autoolytic debridement with hydrogel and hydrocolloid OR Autolytic debridement with hydrogel and 
transparent film OR Autoolytic debridement with hydrogel and non adherent gauze OR Enzymatic debridement with papain gel 1\% OR Enzymatic debridement with papain diluted 10\%; END IF; IF ulcer with moderate amount of exudate and no infection. THEN Use calcium alginate or FIM-SE hydrofiber. ${ }^{10}$

From these rules it is possible to notice that when the "compression" procedure is indicated and ITB $>0.8 \mathrm{mmHg}$, the professional can decide between lifting the lower limbs for half an hour in conjunction with the use of calcium alginate, or use hydrophobic in conjunction with the unna boot application, or elevate the lower limbs for half an hour in conjunction with the use of calcium alginate or hydrofibra and the application of elastic graduated compression bandage. ${ }^{14}$

It is extremely important that the patient is assisted by a multiprofessional team where professionals are able to monitor the impact of their interventions through continuous assessment, since venous ulcers cause social implications in sexuality, generating limitations and changes in the quality of life. Thus, it is evident that in order to better serve the patient with venous ulcer and to provide a better quality of life, it is essential that the topic be discussed within the academy and that there is qualification of health professionals. ${ }^{12}$

\section{Nursing performance in the treatment of venous ulcer in elderly person}

It was suggested that nursing encompasses, through direct care, the promotion of health projects that each person lives and pursues. In order to do so, it is sought throughout the life cycle, to prevent disease and to promote the processes of readaptation after the pathology, to satisfy the basic human needs and the maximum independence in the accomplishment of the activities of the daily life. In this way, nursing care helps the person to manage the health resources of the community, and it is considered advantageous to assume a pivotal role in the context of the team. ${ }^{11}$

Still according to the information gathered in the research of the aforementioned author, in parallel, the nurse in the exercise of his practice faces increasingly demanding and complex challenges, as a result of the increase in the average life expectancy and, consequently, of the prevalence of pathologies chronic diseases, such as venous ulcer.

For Leite et al. ${ }^{14}$ \& Almeida et al., ${ }^{13}$ venous ulcer may be defined as a below-knee ulcer in any part of the leg, including the foot, and is classified as a chronic wound, i.e. a wound that remains stagnant at any stage of the healing process for a period of 6 weeks or more, which requires a structured intervention of nursing care. There are several known etiologies of leg ulcer, with venous origin being the most common with $70 \%$ of cases, followed by those of arterial origin with 10 to $20 \%$ of cases and those with mixed etiology with 10 to $15 \%$ of cases. The main causes of the appearance of leg ulcers are chronic venous hypertension, arterial disease or the combination of the two previous ones. The less frequent causes are neuropathy, infection, vasculitis, neoplasias, blood and metabolic disorders, lymphedema and those of iatrogenic origin. Regarding the role of nursing in the treatment of venous ulcer in the elderly, today, public health nurses (non-specialists) are unaware of the specific therapies for the treatment of venous ulcers and report that the lack of a protocol to support their difficult to treat these patients. ${ }^{15}$

In this sense, the absence of adequate systematization and specialist nurses could be minimized with the help of technology, through the development of a specialist system, for example, that supports the decision-making process of nurses and makes available, in addition to a knowledge base, a database with the potential to support future research in this area to broaden the context and a systematization of care so that nursing can lead the foundation between the direct decision making in the treatment of venous ulcer in the elderly. ${ }^{15,12}$ It is also worth noting that the availability of a database would be of fundamental importance not only from the point of view of data collection for research, but also to support the decision-making process according to the profile of these elderly people and the direct assistance of the nursing. Finally, in order for the success in the use of a decision support system and, consequently, effectiveness of nursing care, consideration should be given to the use of resources that enable the permanent education of nurses on the treatment of wounds, as well as such as the digital inclusion of these nurses for the use of this system. ${ }^{15}$

\section{Conclusion}

Analyzing the studies used in this integrative review, it is concluded that the nurse professional as an active member of the multiprofessional team is of great importance, since it becomes the main link between the patient and the other professionals during the treatment of venous ulcer in the studied population in question. These patients undergoing venous ulcer treatment need special care, which demands greater attention due to their more limited health conditions, and no one better than a nursing professional to know how to give due attention and care.

The results found in the studies show the need for a strategic planning in the construction of a systematization of quality nursing care, seeking to program/implement the care in a humanized way, obeying the needs of each one. Of course, all care presents its difficulties, but it is up to the nursing team to seek to overcome such barriers in order to improve care for their clients according to their implications. An important point to highlight is the scarcity of studies on the subject in question, which left the sample of this work limited. This shows the need for more research in the area, with the aim of improving the standards of care. This study brings as a contribution to nursing the importance of nursing care for an audience that in particular has many limitations, fears and doubts about all the treatment to which it will submit. As the nurse is the closest professional, who remains more time with each patient, it is evident the great importance of this professional and the need for more publications that discuss the theme in focus.

\section{Acknowledgements}

None.

\section{Conflict of interest}

The author declares no conflict of interest.

\section{References}

1. United Nations Department of Economic and Social Affairs (UNDESA), Population division. World population prospects: the 2012 revision. New York: United Nations. 2013; p.1-94.

2. https://ww2.ibge.gov.br/home/estatistica/populacao/censo2010/default. shtm

3. Teixeira I, Guariento ME. Biologia do envelhecimento: teorias, mecanismos e perspectivas. Ciênc Saúde Coletiva. 2010;15(6): 28452857. 
4. Hall J, Buckley HL, Lamb KA,. et al. Point prevalence of complex wounds in a defined United Kingdom population. Wound Repair Regen. 2014;22(6):694-700.

5. Brito CCB. Envelhecimento populacional e os desafios para a saúde pública: análise da produção científica. Rev Kairós Gerontol. 2013;16(3):161-78.

6. Souza MKB, Matos IAT. Percepção do portador de ferida crônica sobre sua sexualidade. Rev Enferm UERJ. 2010;18(1):19-24.

7. Cruz RAO, Nóbrega VKM. Produção científica de enfermagem sobre úlcera venosa: uma análise bibliométrica brasileira. Revista de Enfermagem. 2016;19(2).

8. Tavares TCA, Driele CNG, Thammy RSC, et al. Sistematização da assistência de enfermagem a um paciente portador de úlcera venosa: relato de experiência. Anais do V Congresso de Educação em Saúde da Amazônia. 2016.

9. Mendes KDS, Silveira RCCP, Galvão CM. Revisão integrativa: método de pesquisa para a incorporação de evidências na saúde e na enfermagem. Texto e contexto enferm. 2008;17(4).
10. Sellmer D, Carina MGC, Deborah RC, et al. Sistema especialista para apoiar a decisão na terapia tópica de úlceras venosas. Rev Gaúcha Enferm. 2013;34(2):154-162.

11. Fonseca C, Tiago F, Ana R, et al. A pessoa com úlcera de perna, intervenção estruturada dos cuidados de enfermagem: revisão sistemática da literatura. Rev esc enferm. 2012;46(2):480-486.

12. Santos LSF, Alessandra CLFC, Beatriz GRBO, et al. Influência da úlcera venosa na qualidade de vida dos pacientes: revisão integrativa. Rev enferm UFPE. 2015;9(Supl 3):7710-7722.

13. Almeida WA, Ferreira AM, Maria L, et al. Fatores associados à qualidade de vida de pessoas com feridas complexas crônicas. J res fundam care. 2018;10(1):9-16.

14. Leite DG, Maurício CS, Danielle AFMM, et al. The family health support core (nasf) and health practices: are there many challenges to be overcome?. International Archives of Medicine. 2017:(10).

15. Silva MH, Jesus MCP, Merighi MAB, et al. Limites e possibilidades vivenciados por enfermeiras no tratamento de mulheres com úlcera venosa crônica. Rev Esc Enferm USP. 2014;48(Esp):54-9. 